\title{
Post-graduate Theses on Logistics and Supply Chain in Turkey: A Bibliometric Analysis
}

\author{
Türkiye’de Lojistik ve Tedarik Zinciri Alanlarında Yapılan Lisansüstü Tez \\ Çalışmalarının Bibliyometrik Analizi \\ İbrahim Halil KORKMAZ* \\ Cihan ÇETINKAYA **
}

\begin{abstract}
Turkey's advantageous location connects Europe with Asia and which has seas from all three sides gives a potential for being the world's logistics hub. For these reasons enough attention needs to be given to the improvements in logistics and supply chain in Turkey. The purpose of the study is to reveal how the distribution graduate theses in logistics and supply chain prepared in Turkey according to different criteria from 1993 until today. The data of the research were collected from national thesis center and the obtained data were analyzed and some statistics were obtained. According to this, 525 theses are examined according to their degree, status of university, cities they have been prepared for, years, institutes and key words used. It is reached the result that the majority of master and doctorate theses in logistics and supply chain are written in public universities. The three most studied provinces are Istanbul, Izmir and Ankara. It seems that a limited number of theses were made until 2000. Significant increases have been observed in the theses after 2000. In supply chain field, the highest numbers of theses were written in Istanbul Technical University with 57 theses. In logistics field, the Institute of Social Sciences is the first place followed by the Institute of Natural and Applied and Institute of Defense Science. In supply chain field, Institute of Natural and Applied Sciences is the first and the second is Institute of Social Sciences. Most of the theses in supply chain field were about management.
\end{abstract}

Keywords - Bibliometric analysis; doctorate thesis; logistics; master thesis; supply chain.

$\ddot{\mathbf{O z}}$

Türkiye'nin üç tarafı denizlerle çevrili olan ve Asya ile Avrupa kıtalarını birbirine bağlayan avantajlı coğrafi konumu, dünyanın lojistik merkezi olma noktasında ülkeye potansiyel sunmaktadır. Bu nedenle Türkiye'de, lojistik ve tedarik zinciri alanlarına yeterince ilgi gösterilmesi büyük önem arz etmektedir. Bu çalışmanın amacı, Türkiye'de, lojistik ve tedarik zinciri alanlarında 1993 yılından günümüze kadar hazırlanan lisansüstü tez çalışmalarının çeşitli kriterlere göre dağılımını ortaya çıkarmaktır. Araştırma için Ulusal Tez Merkezi’nden elde edilen veri, çeşitli istatistiksel analiz yöntemleriyle incelenmiştir. Bu kapsamda, 525 tez derecelerine, hazırlandıkları üniversiteye, şehire, yıla, enstitüye ve kullanılan anahtar kelimelere göre değerlendirilmiştir. Sonuç itibarıyla lojistik ve tedarik zinciri alanlarında hazırlanan tezlerin büyük bir kısmının devlet üniversitelerinde hazırlandığı tespit edilmiştir. En çok lisansüstü tez çalışması yapılan iller İstanbul, İzmir ve Ankara'dır. Bu çalışmaların az sayıda kısmının 2000 yılından önce yapıldığı görülmektedir. Tedarik zinciri alanında yapılan 57 çalışma ile İstanbul Teknik Üniversitesi, bu alanda en çok çalışma yapılan üniversite olmuştur. Lojistik alanında, en çok lisansütsü çalışma yapılan Sosyal Bilimler Enstitülerini Doğa ve Uygulamalı Bilimler Enstitüleri ve Savunma Bilimleri Enstitüleri takip etmiştir. Tedarik zinciri alanında ise, Doğa ve Uygulamalı Bilimler Enstitüleri birinci sıradayken, ikinci sırayı Sosyal Bilimler Enstitüleri almıştır. Tedarik zinciri alanında hazırlanan tezlerin büyük bir kısmı yönetime ilişkindir.

Anahtar Kelimeler - Bibliometrik analiz; doktora tezi, lojistik, yüksek lisans tezi, tedarik zinciri.

\section{Introduction}

In the period after the 1950s, most producers focused on mass production systems, with little product and process flexibility as the basic operational strategy, to minimize unit production costs (Özdemir, 2004). During this period, the development of new products was

\footnotetext{
*Dr., Gaziantep University, İslahiye Vocational School, E-mail: ihalil@yahoo.com

** Doç. Dr., Adana Science and Technology University Management Information Systems Department,

E-mail: cihancetinkaya@ gmail.com Dr., Gaziantep University, İslahiye Vocational School, ihalil@yahoo.com
}

Korkmaz, H. İ., Çetinkaya, C., (2019). Post-graduate Theses on Logistics and Supply Chain in Turkey: A Bibliometric Analysis, Gaziantep University Journal of Social Sciences, 18 (1), 479-493, Submission Date: 2605-2018, Acceptance Date: 22-01-2019.

Araştırma Makalesi. 
slow and completely dependent on in-house technology and capacity. Bottleneck activities were met with inventories to maintain a balanced line flow, resulting in large investments in semi-finished stocks. In this period, sharing technology and expertise with customers or suppliers seemed too risky and unacceptable. In the same way, it was seen that there was very little interest in cooperation between enterprises and buyer-supplier partnership (Tan, 2001). From the beginning of the 1990s, the situation is now very different. At the heart of business decisions are now customers. Businesses are striving to improve the way in which all members of the value chain, including suppliers, producers, and retailers, collaborate to satisfy their customers. The name of this cooperation period is named Supply Chain Management (Houlihan, 1985).

As a concept that includes all business processes from planning to resource use to production to distribution, supply chain management is about all parties, from the original supplier to the final consumer (Tozanli et. al, 2017). Supply Chain Management is a model that provides regular control and coordination of inter-firm processes, reduces costs, increases quality and speeds up activities. According to this model winners of competition conditions will be companies that can approach new business approaches, work beyond traditional business boundaries, and work closely with business partners to design and manage business processes. They are firms that can leap from the effectiveness to super effectiveness (Hammer, 2001). Sharing information and plans with suppliers and customers can increase chain efficiency and competitiveness. In the changing world, companies are no longer talking about competition among themselves. Competition will now be among the supply chains within firms (Kehoe and Boughton, 2001).

Bowersox (1969) first emphasized the physical distribution phase, which is considered as the first stage of supply chain management. In addition to observing related flows in the context of physical distribution, he suggests that the distribution function will provide a competitive advantage with intra-firm, intra-channel integration. After the introduction of the Material Requirements Planning (MRP) system in the 1970s, managers understood the significant impact of in-process work on the cost of production, quality, new product development and delivery times at delivery. Thus, instead of reducing the cost of each operation, a cost approach has been developed for all logistics services that take the entire system as a whole (Ross, 1998).

Houlihan (1985) has presented a strong approach that considers the supply chain as a single phenomenon, combining the firm's strategic decisions with logistical focus. He thus became the first to use the term supply chain for this system in the literature (Ganeshan et al. 1999). Increasing global competition in the 1980s forced companies in world class to offer reliable products at a lower cost, higher quality and more design flexibility. During this period, the logistics phase, which is now the second stage of supply chain management, has been passed (Metz, 1998). This stage is expressed by Ross (1988) as the integration of logistics. After the mid-1990s, managers realized that goods and services received from suppliers had a significant effect on the ability of the firm's customers to meet their needs. It has become a new success method to deliver products at a cost-effective way when, where, how and at what amount. Thus, they understood that it is necessary to take part in the management of the entire network of upstream companies that provide input to them, as well as the entire network of downstream companies delivering the latest customer products and providing after sales services (Handfield and Nicholas, 1999).

Over the past decade, it has been seen that companies are placing an increasing emphasis on supply chain and logistics so that they can gain competitive advantage in markets. There are a number of examples that companies are making big investments in order to improve their customer satisfaction and internal productivity. In fact, today's competition is 
not among individual companies; more and more, there is competition between rival supply chains. Supply chains that add the most value to customers at the lowest cost create a network that increases the earnings of individual companies (Christopher, 1998). Under the success of firms that can survive in the competitive world, it is the efficient design, planning and execution of supply chains. The performance of a supply chain depends on a balance between customer responsiveness and financial efficiency (Chopra and Meindl, 2016).

Infrastructure of logistics industry in Turkey was created in between 1980's and 1990's, with the help of investments into land, air, sea and railway transportation and received it's breakthrough in 1990's. By the beginning of 2000's logistics sector in Turkey left behind its infancy and became a dynamic sector, which cooperates with international organizations, opens overseas branches and continuously improves its quality (Babacan, 2003).

Logistics industry has been developing rapidly in recent years, as growth potential it carries in itself, as well as of major importance in many fundamental role to play in achieving economic targets in Turkey. The worldwide volume of logistics services, including transportation, warehousing, packaging, customs clearance and ultimate consumer access, is increasing steadily. Logistics infrastructure seems to be more effective and productive in developed countries' trade activities. The most important goal for the logistics industry in Turkey, in parallel with the economic growth rate, increasing the share of receivables from GNP of developed countries as in the logistics sector and is entered among the top 15 countries in the Logistics Performance Index. In this context, in the Tenth Five-Year Development Plan "ensuring Turkey as a regional power in logistics; lowering logistics costs, improving trade and increasing competition power" determined as the main objective (Ministry of Development, 2013).

Logistics providing competitive advantages in Turkey, has become an increasingly important sector. Turkey, despite the civil war in Syria crisis and the problems in Europe, has managed to capture the growth in the logistics sector (Afatoğlu, 2013).

Turkey's advantageous location which connects Europe with Asia and which has seas from all three sides gives a potential for being the world's logistics hub. For these reasons enough attention needs to be given to the improvements in logistics and supply chain in Turkey.

The aim of this study is to reveal a general profile of master and doctorate theses and to determine the distribution of the methods used in these theses over the years, which are written in Turkish universities in the field of supply chain and logistics between the years 1993 and 2017. Accordingly, in addition to determining in which years, languages, universities, institutes, cities, status and degrees of theses, the theses are examined in their application areas and in which topics they are concentrated. This research, which allows seeing the master and doctoral theses related to the subject in a collective way, is anticipated to be the guide to future research about supply chain and logistics.

\section{Methodology}

The objective of this study is to reveal a general profile of master and doctorate theses about logistics and supply chain from Thesis Center of Turkish Higher Education. The first step is to define the objective of the study. The second step is to define which statistics we need or what will be the output of our study. The third step is to find out which data we need in order to draw the statistics and where we can get them. The next step is to collect the data from the database we have decided on. After that we sort the data with spreadsheet. The sixth step is to infer the statistics from the data collected. And the last step is to draw conclusions about the whole project. These steps can be seen in Figure 1. 


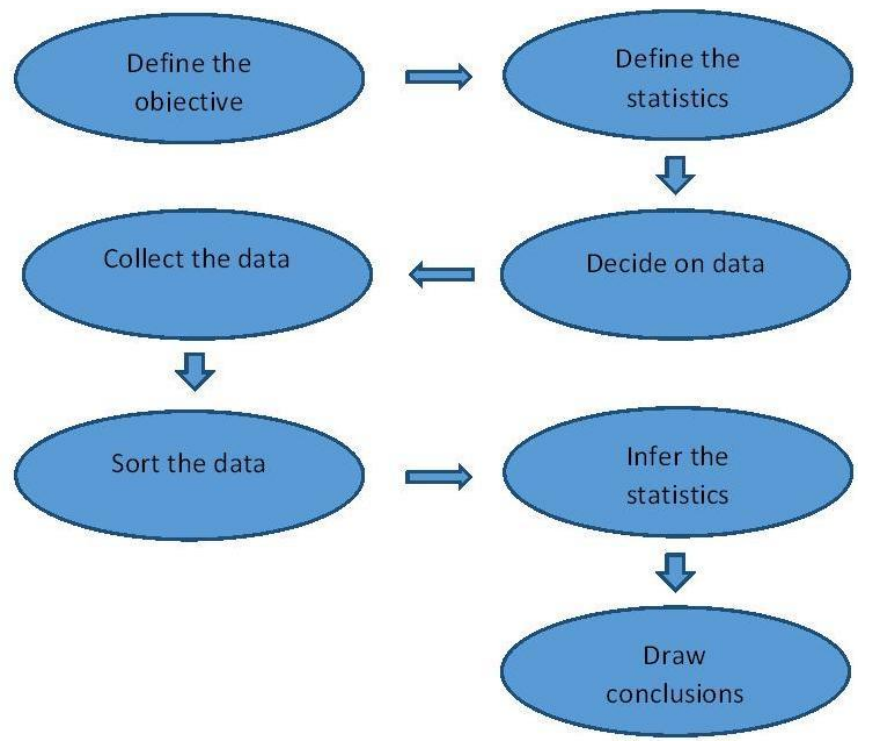

Figure 1: Methodology

Bibliometry is the use of mathematical and statistical methods to analyze a discipline using data from the disciplinary publications. The data included in the analysis consist of authors, references, sources, topics, countries or institutions where they were produced, and years of publication. In this sense, a general view of a discipline with bibliometric analysis can be made by examining such data from publications using mathematical and statistical methods (Martinez et. al., 2015). In accordance with the purpose of the study, use of bibliometric analysis method would be appropriate and useful for examining theses written in Turkey in logistics and supply chain areas. Within the scope of the study, SPSS 22 and Excel package softwares were used for the data analysis.

\section{Findings}

\section{The Distribution of Theses in the Field of Logistics and Supply Chain According to Degree}

The distribution of master and doctorate theses between 1993 and 2017 in the field of logistics according to their degrees is shown on the Figure 2.

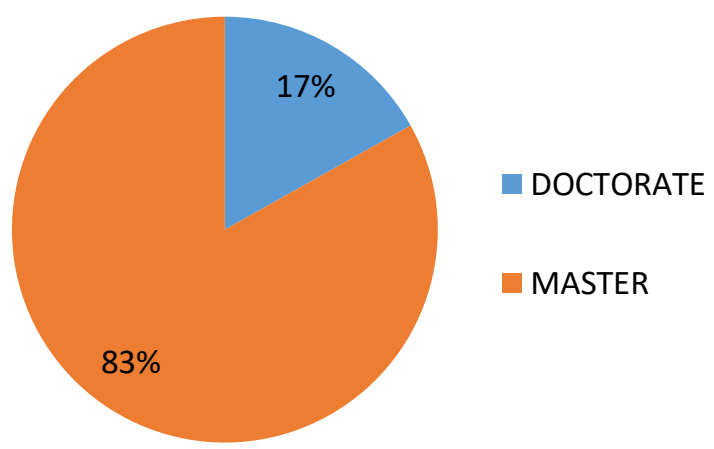

Figure 2: Distribution of theses in the field of logistics according to degree

Looking in the Figure 2, it is seen that most of the current theses in the logistics field are composed of master theses. Also in Figure 2 it is seen that $83 \%$ of the theses are composed of doctorate theses and $17 \%$ of them are master theses. These findings, at the graduate level in the field of logistics in Turkey show clearly that the limited number of studies carried out in the doctorate field. It is thought that the reason that the numbers of the 
theses made differ so much according to the degrees is that the majority of the universities provide master education than doctorate education (Ahi and Kildan, 2013).

The distribution of master and doctorate theses between 1998 and 2017 in the field of Supply Chain according to their degrees is shown on the Figure 3.

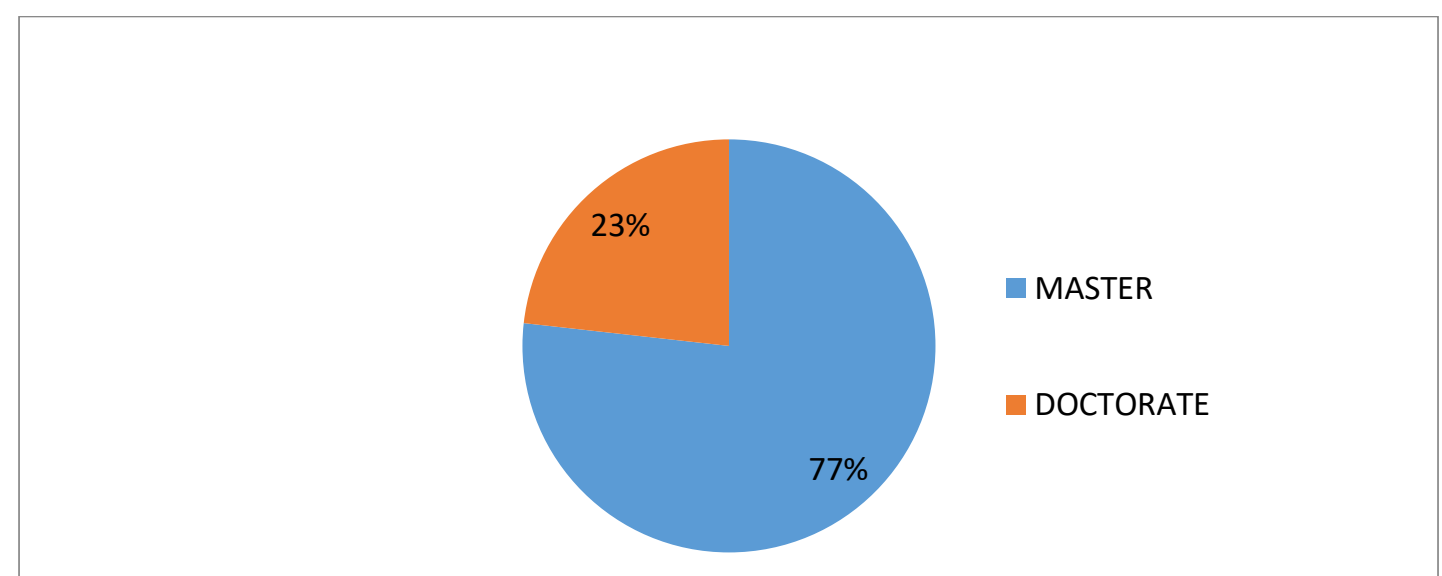

Figure 3: Distribution of theses in the field of supply chain according to degree

As in the field of logistics, in supply chain most of the theses are master theses. From the Figure 3 we can see that $77 \%$ are master and $23 \%$ are doctorate. These findings show clearly that limited number of studies is carried out in doctorate field.

\section{The Distribution of Theses in the Field of Logistics and Supply Chain According to Language} language.

In Figure 4, it is shown the distribution of theses in the field of logistics according to

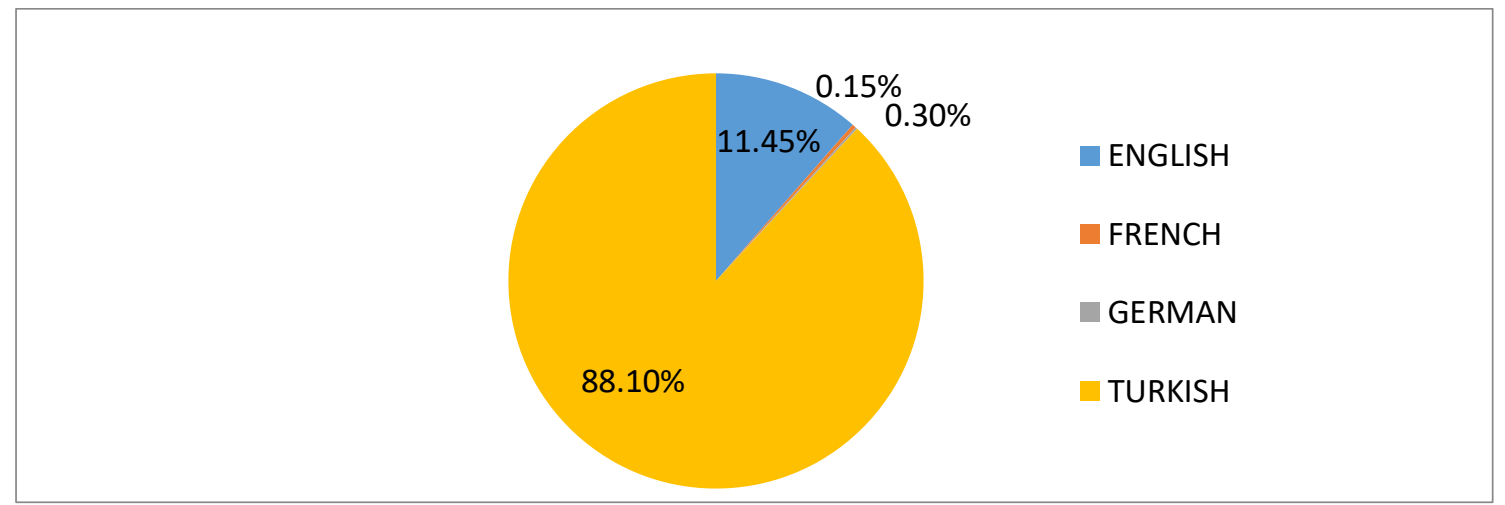

Figure 4: Distribution of theses in the field of logistics according to language

In the Figure 4 , it is found that $88.1 \%$ of the theses are in Turkish, $11.45 \%$ are in English, and also very low in French and German. It is obtained the result that theses in the field of logistics in Turkey written mostly in Turkish. Other than Turkish, English is the most widely used language in theses. Distribution of theses according to language, in the field of supply chain is shown in Figure 5. 


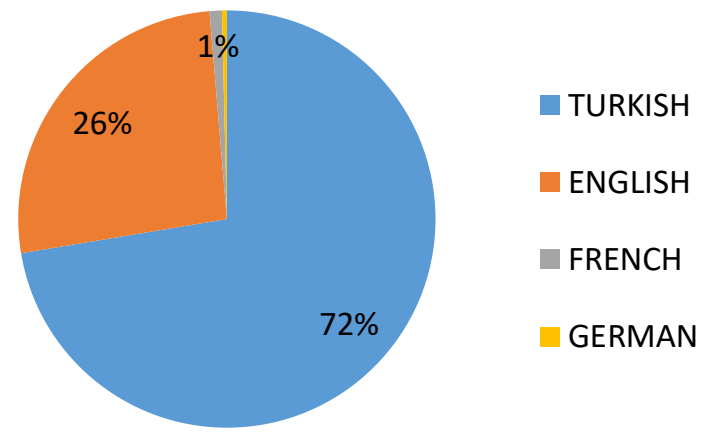

Figure 5: Distribution of theses in the field of supply chain according to language

As can be seen in Figure 5, it is found that most of the theses in the field of supply chain are in Turkish and English. 72\% of theses in Turkish, 26\% in English and 2\% of them are in French and German. Although, only $26 \%$ of theses are currently in English it is gaining popularity year by year.

\section{The Distribution of Theses in the Field of Logistics and Supply Chain According to Status of the University}

According to the status of the university, the distribution of theses in the field of logistics is given in the Figure 6 below.

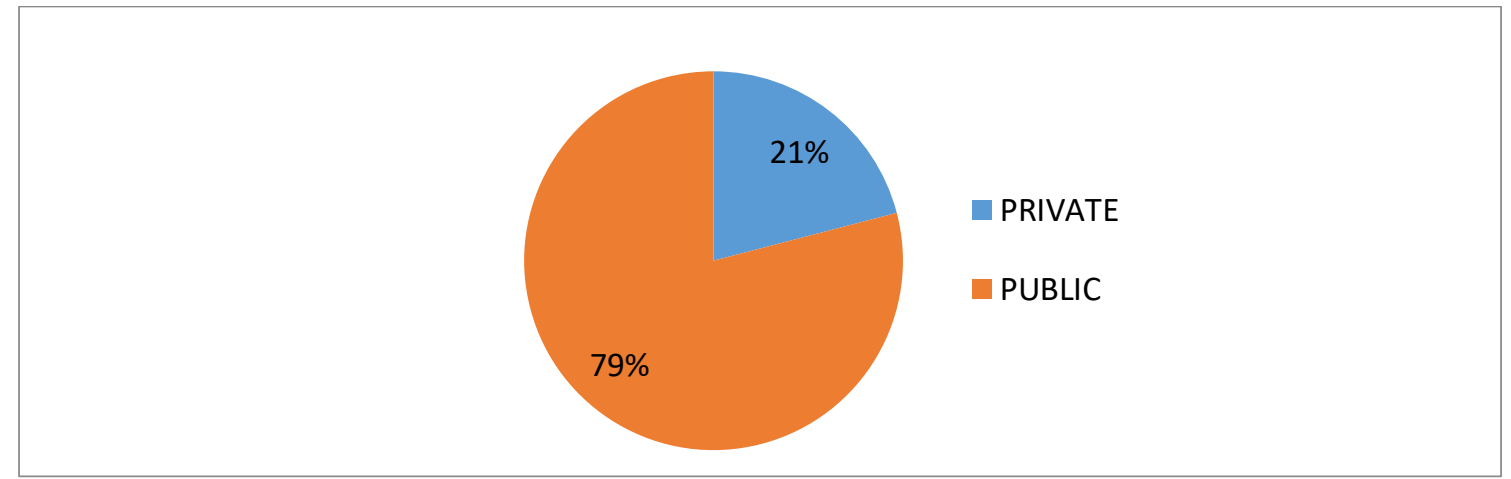

Figure 6: Distribution of theses in the field of logistics according to status of university

Looking in the Figure 6, it is reached the result that the majority of master and doctorate theses in logistics are written in public universities. According to the obtained graph in Figure 6,79\% of the theses are made in public universities and $21 \%$ of theses are made in private universities. It is thought the reasons of theses are mostly carried out in public universities are that the number of these universities is high and the numbers and titles of faculty members are sufficient to open these programs and the infrastructures of existing programs in these universities are established (Ahi and Kildan, 2013). According to the status of the university, the distribution of theses in the field of supply chain is given in the Figure 7 below. 


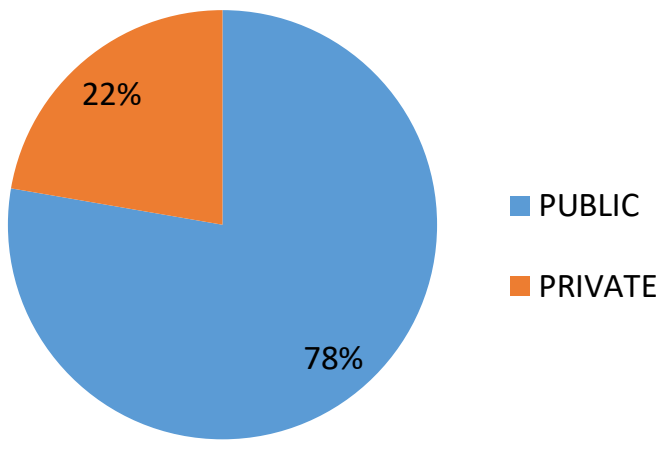

Figure 7: Distribution of theses in the field of supply chain according to status of university

From Figure 7, it can be deducted that majority of graduate theses in the field of supply chain are written in public universities. It is seen that $78 \%$ of the theses are written in public universities and $22 \%$ are in private universities. The reasons for these are the same as in logistics. There are more public universities in Turkey, faculty members are sufficient to open these programs and because private universities are mostly new infrastructures for these programs are not established.

\section{The Distribution of Theses in the Field of Logistics and Supply Chain According to Cities}

The distribution of theses made in the field of logistics according to cities is shown in the Figure 8 below.

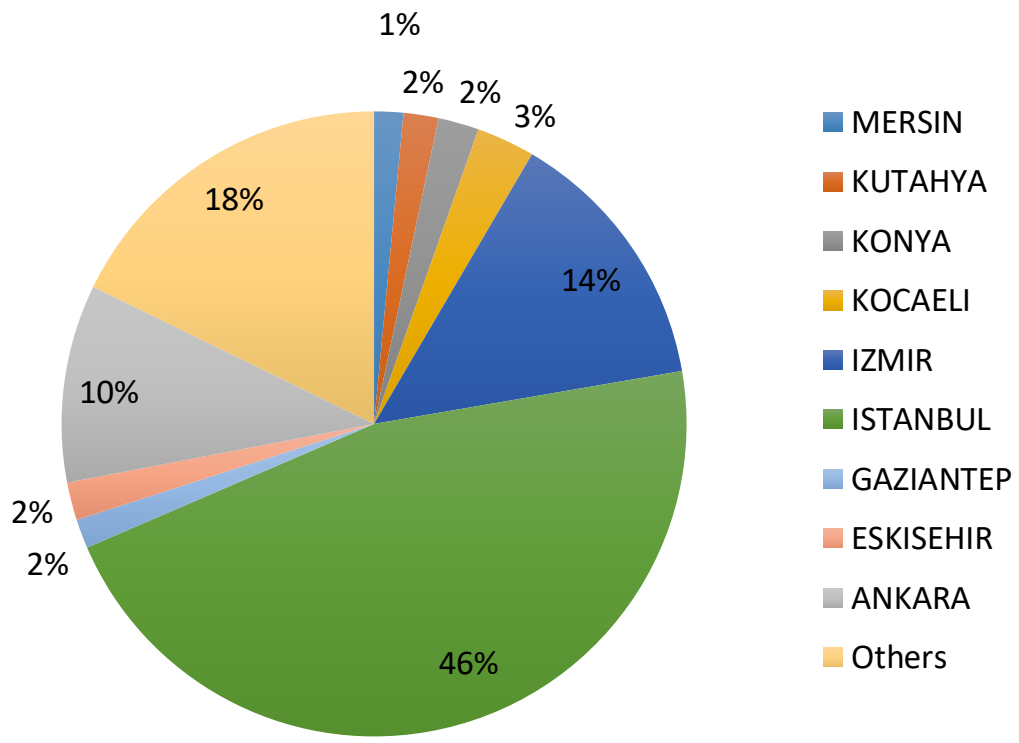

Figure 8: Distribution of theses in logistics according to cities

In the Figure 8, it is seen that the majority of theses made in logistics often occurs in some cities of Turkey. The three most studied provinces are Istanbul, Izmir and Ankara. And these 3 cities constitute $70 \%$ of the theses written. In addition, very few thesis studies have been conducted in many other cities. And these cities are shown on the chart in the Figure 8 as the others. It is thought the reasons for the theses being mostly written in some cities are that a large part of the logistics industry is located in these cities and the number of universities that includes logistics department is high. The distribution of theses made in the field of supply chain according to cities is shown in the Figure 9 below. 


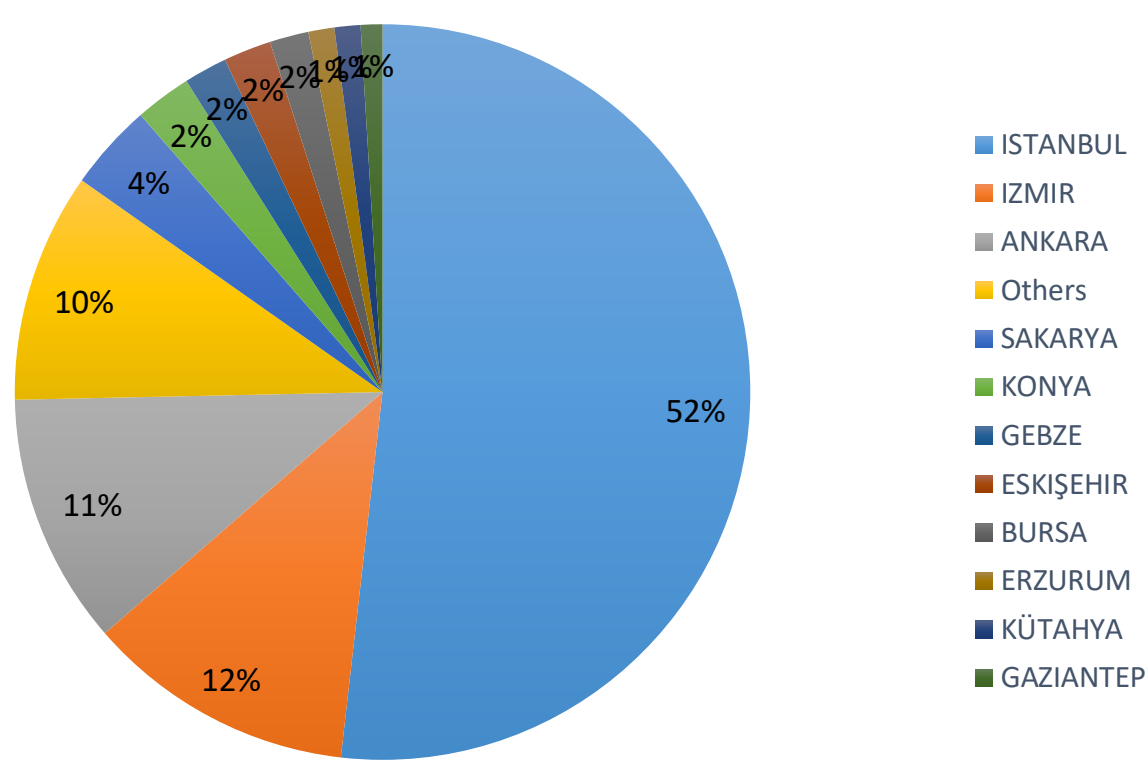

Figure 9: Distribution of theses in supply chain according to cities

In the Figure 9, it is seen that the majority of theses made in logistics often occur in few cities of Turkey. Three most studied provinces are the same as in logistics, Istanbul, Izmir and Ankara. About $75 \%$ of them are written in these three provinces. And in most of the other provinces very low percentage of theses are written. They constitute $10 \%$ of overall theses, they are written as others in the figure. The reason for these is thought that, most of the universities high ranked universities are located in these cities and the demand for supply chain experts are higher in those cities.

\section{The Distribution of Master and Doctorate Theses in the Field of Logistics and Supply Chain Per Year}

The distribution of master and doctorate theses in the field of logistics between 1993 and 2017 according to years is shown in Figure 10.

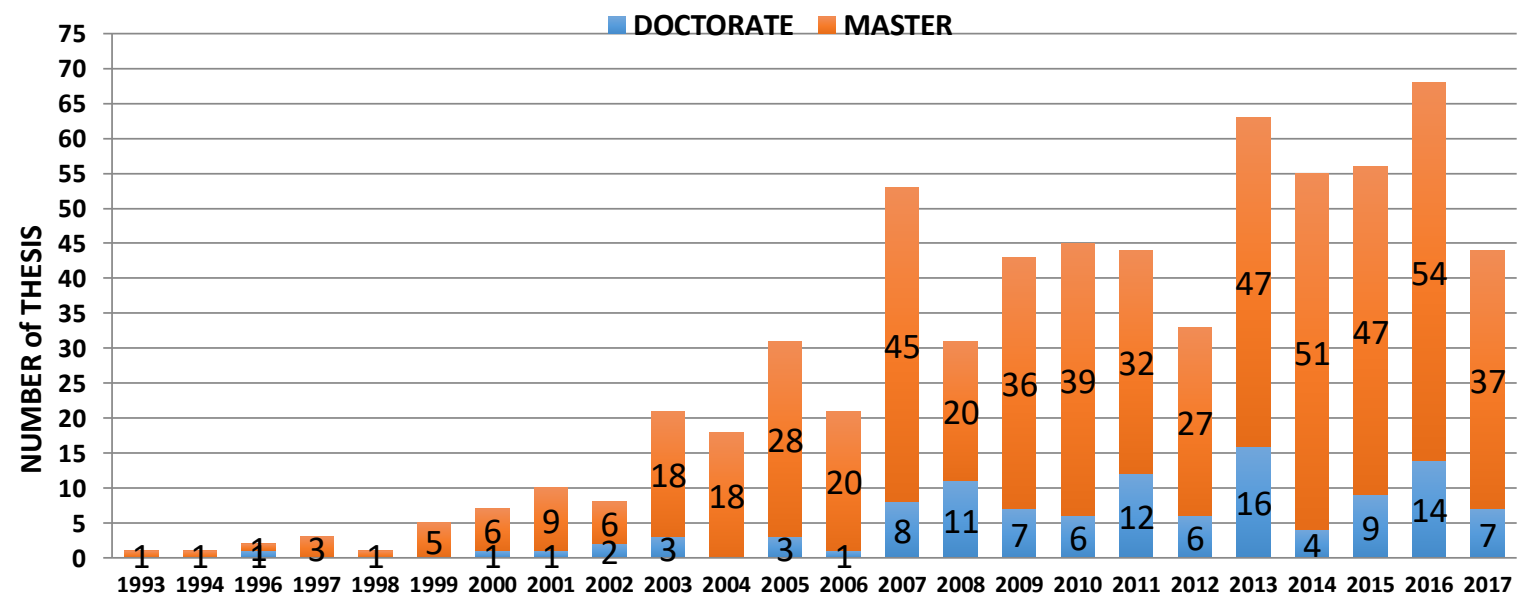

Figure 10: Distribution of master and doctorate theses in logistics per year

Looking in the Figure 10, it seems that a limited number of master theses were made until 1999. Significant increases have been observed in the theses since 1999. It is noteworthy that the number of theses has decreased again in the following years. It is determined that the highest number of master theses is written in 2016 and this number is 54. It seems that a limited number of doctorate theses were made until 2007. Significant increases are seen in the doctorate theses published together with the year 2007. And it is understood that most number 
of the doctorate thesis is published in 2013 as 16 . From 1993 to the end of 2017, a total of 664 theses that are 552 master and 112 doctorate theses were published in the national thesis center. Looking at these data, it is noteworthy that logistics theses mainly consist of master theses. The distribution of master and doctorate theses in the field of logistics between 1998 and 2017 is shown in Figure 11.

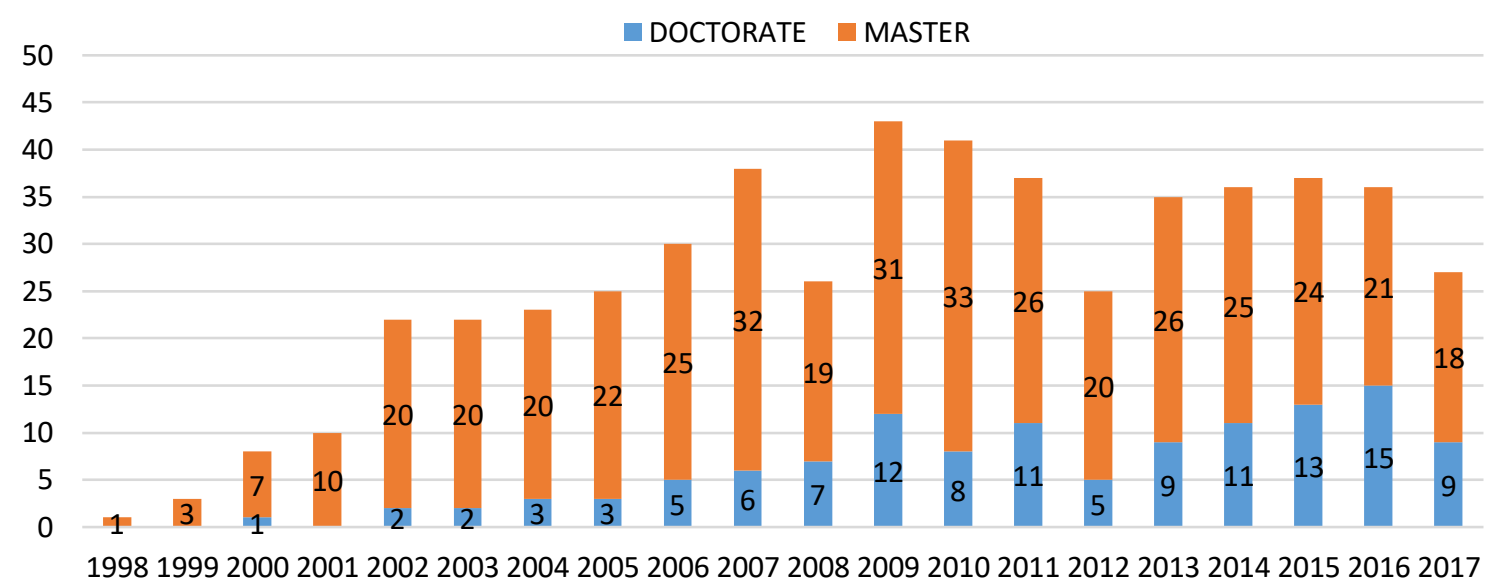

Figure 11: Distribution of master and doctorate theses in supply chain per year

Until the year of 2002 small fraction of master theses were written in the field of supply chain. However there has been an increase in number since then except for the years 2008, 2012 and 2017. Highest number of master theses were written in the year 2010 being 33. Doctorate theses weren't very significant until the year 2007. It also has been growing except for the year 2012. The highest number of doctorate theses were written in the year 2016 being 15 . From the year 1998 to 2017 total 525 theses were written, 403 of them being master and 122 doctorate.

\section{The Distribution of Master and Doctorate Theses in the Field of Logistics and Supply Chain According to Cities}

The distribution of master and doctorate theses in the field of logistics according to cities is shown in Figure 12.

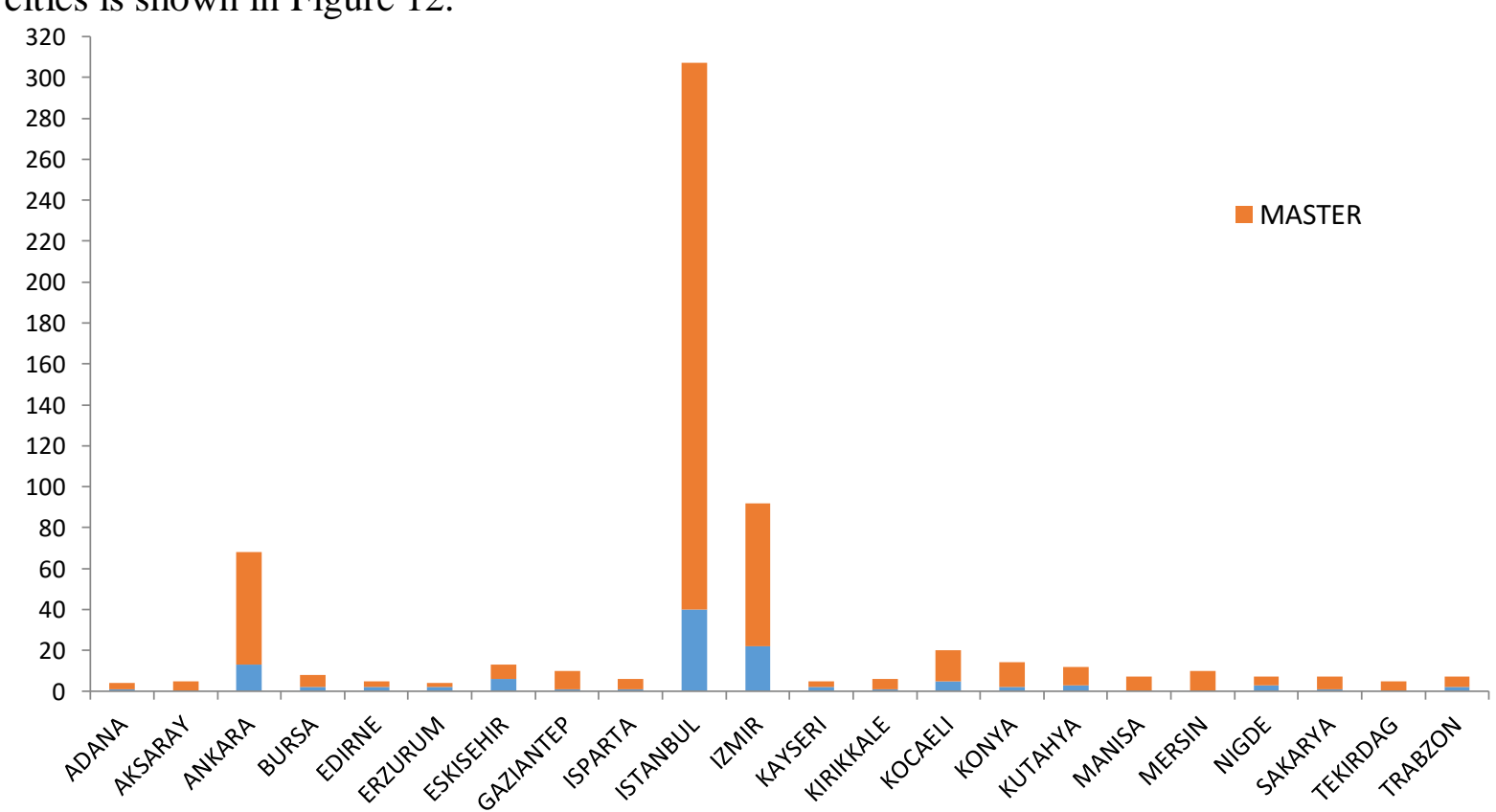

Figure 12: Distribution of master and doctorate theses in logistics according to cities 
It is seen that Istanbul, Izmir and Ankara are three provinces in the logistics areas with the most thesis written. And it is seen that Istanbul is the province where most master and doctorate thesis are written. In some cities, the doctorate thesis is not written. It can be obtained the result that most cities have very few theses made in logistics. In Table 1, we can see the top 10 universities with the most number of theses written in the field of logistics. The highest numbers of theses were written in Dokuz Eylül University which is 70. All of them are located in below mentioned three cities Istanbul, Izmir and Ankara.

Table 1: Top universities with the total number of theses in field logistics

\begin{tabular}{|l|c|c|}
\hline UNIVERSITY & NUMBER & PERCENTAGE \\
\hline DOKUZ EYLUL UNIVERSITY & 70 & 10.54 \\
\hline MARMARA UNIVERSITY & 61 & 9.19 \\
\hline ISTANBUL TECHNICAL UNIVERSITY & 60 & 9.04 \\
\hline ISTANBUL UNIVERSITY & 33 & 4.97 \\
\hline GAZI UNIVERSITY & 29 & 4.37 \\
\hline YILDIZ TECHNICAL UNIVERSITY & 29 & 4.37 \\
\hline TURKISH MILITARY ACADEMY & 18 & 2.71 \\
\hline BAHCESEHIR UNIVERSITY & 15 & 2.26 \\
\hline OKAN UNIVERSITY & 15 & 2.26 \\
\hline BEYKENT UNIVERSITY & 12 & 1.81 \\
\hline
\end{tabular}

The distribution of master and doctorate theses in the field of supply chain according to cities is shown in Figure 13.

DOCTORATE MASTER

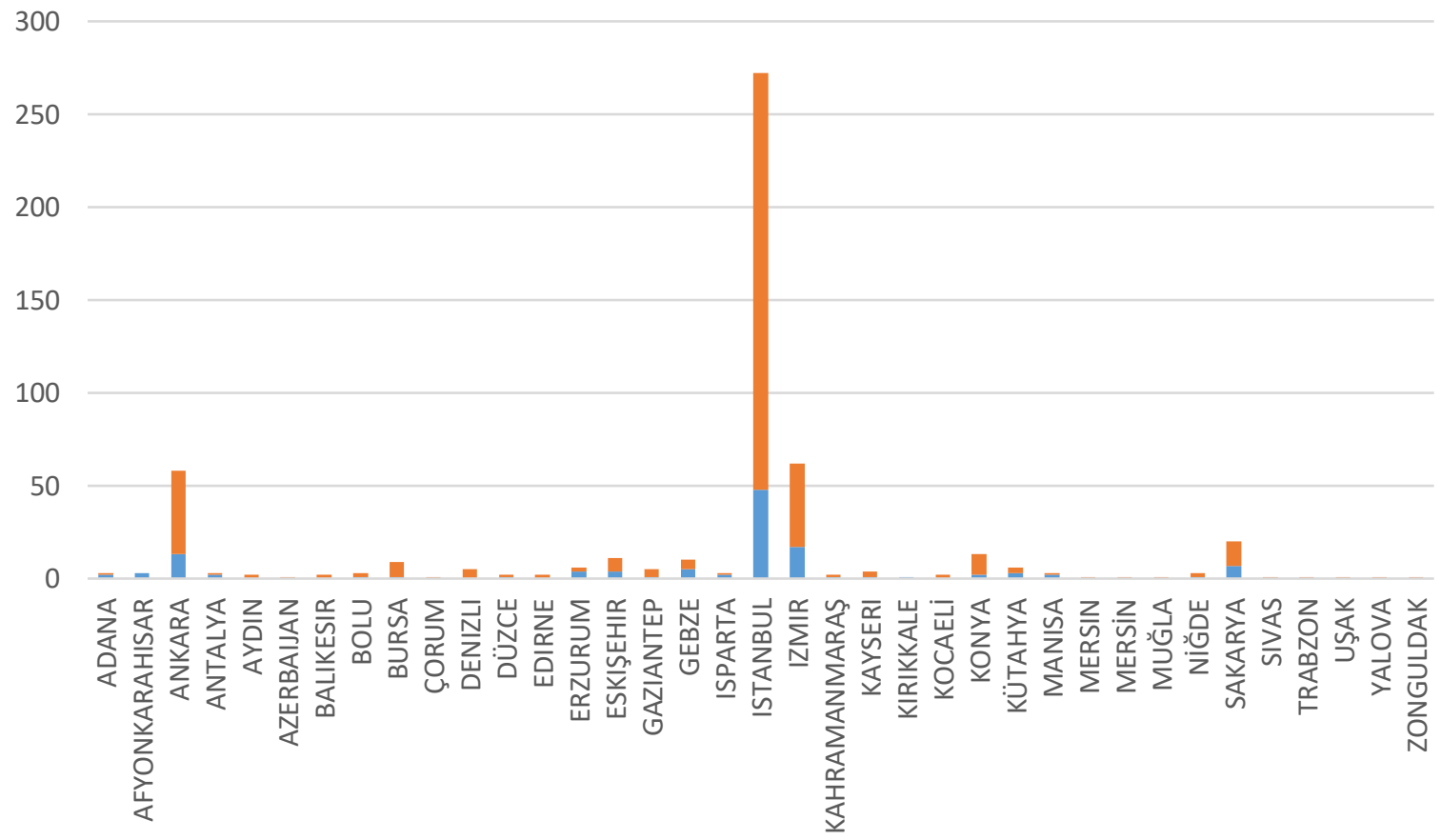

Figure 13: Distribution of master and doctorate theses in supply chain according to cities

It can be seen from Figure 13 that most of the master and doctorate theses are written in cities Istanbul, Izmir and Ankara. It is noteworthy that in some cities there are no doctorate theses. Also in Table 2, we can see the top 10 universities with the most number of theses written in the field of supply chain. First is Istanbul Technical University with 57 theses. Almost all of them are located in above mentioned three cities Istanbul, Izmir and Ankara. 
Table 2: Top universities with the total number of theses in field supply chain

\begin{tabular}{|lcc|}
\hline UNIVERSITY & NUMIBER & PERCENTAGE \\
\hline ISTANBUL TECHNICAL UNIVERSITY & 57 & 10.86 \\
\hline DOKUZ EYLUL UNIVERSITY & 43 & 8.19 \\
\hline MARMARA UNIVESRITY & 39 & 7.43 \\
\hline YILDIZ TECHNICAL UNIVERSITY & 28 & 5.33 \\
\hline ISTANBUL UNIVERSITY & 27 & 5.14 \\
\hline GAZI UNIVERSITY & 23 & 4.38 \\
\hline BOGAZICI UNIVERSITY & 22 & 4.19 \\
\hline SAKARYA UNIVERSITY & 20 & 3.81 \\
\hline BAHCESEHIR UNIVERSITY & 17 & 3.24 \\
\hline MIDDLE EAST TECHNICAL UNIVERSITY & 16 & 3.05 \\
\hline
\end{tabular}

\section{The Distribution of Master and Doctorate Theses in the Field of Logistics and Supply Chain According to Institute of University}

The distribution of master and doctorate theses in the field of logistics according to institutes is shown in Table 3. Master and doctorate theses in the field of logistics were carried out in 11 institutes.

Table 3: Distribution of master and doctorate theses in logistics according to the institutes

\begin{tabular}{|lccc|}
\hline Institute & Doctorate & Master & Total \\
\hline SOCIAL SCIENCES & 81 & 320 & 401 \\
\hline NATURAL AND APPLIED SCIENCES & 25 & 187 & 212 \\
\hline DEFENSE SCIENCES & 2 & 17 & 19 \\
\hline NAVAL SCIENCES AND ENGINEERING & 0 & 8 & 8 \\
\hline MARINE SCIENCES AND MANAGEMENT & 1 & 6 & 7 \\
\hline EDUCATION SCIENCES & 1 & 4 & 5 \\
\hline ENGINEERING AND APPLIED SCIENCES & 0 & 4 & 4 \\
\hline FOREIGN TRADE & 0 & 3 & 3 \\
\hline ATATURK'S PRINCIPLES AND HISTORY OF TURKISH REVOLUTION & 0 & 2 & 2 \\
\hline RESEARCH INSTITUTE OF TURKOLOGY & 2 & 0 & 2 \\
\hline STRATEGIC RESEARCH & 0 & 1 & 1 \\
\hline Grand Total & $\mathbf{1 1 2}$ & $\mathbf{5 5 2}$ & $\mathbf{6 6 4}$ \\
\hline
\end{tabular}

When we look at the completed theses in the field of logistics at the institute level, the Institute of Social Sciences is the first place followed by the Institute of Natural and Applied and Institute of Defense Science. When Table 3 is examined, it is seen that $60.39 \%$ of the thesis studies in the field of logistics are carried out in the Social Sciences and $31.92 \%$ in the Natural and Applied Science. It is received the result from Table 3 that some institutes only have master theses and some have only doctorate theses. Also it is received that $57.97 \%$ of graduate theses and $72.32 \%$ of doctoral theses were done at Institute of Social Sciences. The distribution of master and doctorate theses in the field of supply chain according to institutes is shown in Table 4. Master and doctorate theses in the field of supply chain were carried out in 11 institutes.

Table 4: Distribution of master and doctorate theses in supply chain according to the institutes

\begin{tabular}{|lccc|}
\hline Institute & Doctorate & Master & Total \\
\hline NATURAL AND APPLIED SCIENCES & 45 & 212 & 257 \\
\hline SOCIAL SCIENCES & 72 & 174 & 246 \\
\hline ENGINEERING AND APPLIED SCIENCES & 1 & 8 & 9 \\
\hline DEFENCE SCIENCES & 1 & 2 & 3 \\
\hline AVIATION AND SPACE TECHNOLOGIES & 1 & 1 & 2 \\
\hline HEALTH SCIENCES & 0 & 2 & 2 \\
\hline INFORMATICS & 0 & 2 & 2 \\
\hline BUSINESS ADMINISTRATION & 1 & 0 & 1 \\
\hline
\end{tabular}




\begin{tabular}{|lccc|}
\hline EDUCATIONAL SCIENCES & 1 & 0 & 1 \\
\hline STRATEGIC RESEARCH & 0 & 1 & 1 \\
\hline ABROAD & 0 & 1 & 1 \\
\hline Grand Total & $\mathbf{1 2 2}$ & $\mathbf{4 0 3}$ & $\mathbf{5 2 5}$ \\
\hline
\end{tabular}

When we look at the completed theses in the field of supply chain at the institute level, the Institute of Natural and Applied Sciences and the Institute of Social Sciences constitute most of the theses with $95.81 \%$. With the total of $52.60 \%$ of master theses and $36.88 \%$ of doctorate theses Institute of Natural and Applied Sciences is the first in the list. The second is Institute of Social Sciences which has $43.18 \%$ of master and $59.02 \%$ of doctorate theses. Other institutes consist less than $5 \%$ of all theses. Also it can be seen from the table $2 b$ that some institutes have only master theses and some have only doctorate theses.

\section{The Distribution of the Most Used Keywords in Theses in the Field of Logistics and Supply Chain}

The distribution of the most used keywords in theses in the field of logistics is seen on Table 5 below. The numbers and probabilities of the 10 most used keywords from total 2964 keywords used in the theses are shown in Table 5.

Table 5: Distribution of the most used 10 keywords in theses in the field of logistics

\begin{tabular}{|l|c|c|}
\hline Key Words & Number & Percentage \\
\hline Logistics & 324 & 10.93 \\
\hline Logistic management & 88 & 2.96 \\
\hline Supply chain management & 55 & 1.85 \\
\hline Reverse logistics & 54 & 1.82 \\
\hline Outsourcing & 52 & 1.75 \\
\hline Logistic sector & 40 & 1.34 \\
\hline Third party logistics & 37 & 1.24 \\
\hline Supply chain & 35 & 1.18 \\
\hline Analytical hierarchy process & 32 & 1.07 \\
\hline Transportation & 25 & 0.84 \\
\hline Others & 2222 & 74.96 \\
\hline Total & $\mathbf{2 9 6 4}$ & $\mathbf{1 0 0}$ \\
\hline
\end{tabular}

According to Table 5, the logistic word used 324 times in theses is the most used key word. The most used logistics keyword is used at the rate of $10.93 \%$. This is followed by the logistics management key word used 88 times. The second most used logistic management keyword was used at the rate of $2.96 \%$. This number is followed by supply chain management with 55 and reverse logistics with 54. The distribution of the most used keywords in theses in the field of supply chain is seen on Table 6 below. 
Table 6: Distribution of the most used keywords in theses in the field of supply chain

\begin{tabular}{|lcc|}
\hline Keyword & Total & Percent \\
\hline Supply chain management & 318 & 14.82 \\
\hline Supply chain & 277 & 12.91 \\
\hline Performance & 89 & 4.15 \\
\hline Logistics & 52 & 2.42 \\
\hline Integration & 26 & 1.21 \\
\hline Information technology & 25 & 1.16 \\
\hline Inventory management & 21 & 0.98 \\
\hline Network design & 21 & 0.98 \\
\hline Simulation & 21 & 0.98 \\
\hline Supplier selection & 20 & 0.93 \\
\hline Analytical hierarchy process & 18 & 0.84 \\
\hline Supplier management & 17 & 0.79 \\
\hline Closed loop supply chain & 14 & 0.65 \\
\hline Automotive sector & 13 & 0.61 \\
\hline Information sharing & 12 & 0.56 \\
\hline Enterprise Resource Planning & 10 & 0.47 \\
\hline Computer software & 9 & 0.42 \\
\hline Construction sector & 8 & 0.37 \\
\hline Other & 1175 & 54.75 \\
\hline Total & $\mathbf{2 1 4 6}$ & 100.00 \\
\hline
\end{tabular}

We can draw some conclusions from the table above, such as the most of the theses in supply chain field were about management $14.82 \%$. After that performance was one of the most used keywords $4.15 \%$. It constitutes the terms such as performance measurement and performance evaluation. Supply chain integration and integrated production distribution was also one of the most used keywords $1.21 \%$, meaning that supply chain is evaluated considering also it's integration with production. Information technology and Information sharing was also one of the most used keywords highlighting the importance of Information technology in Supply chain network. Other keywords that weren't used a lot are in the field others in the table. They constitute $54.75 \%$ of all the keywords. In order to find the most used keywords, proposed algorithm which is given in Appendix has been used. It is written in Visual Basic and used as a macro to Excel.

\section{Conclusion}

This study provides analysis of graduate theses written on logistics and supply chain in Turkey between 1993 and 2017. In this context, the concepts of logistics and supply chain were defined, the historical development of theses written on logistics and supply chain areas in Turkey was examined and analyzed. The results obtained from this study aimed to examine the multidimensional analysis of logistics and supply chain graduate theses in Turkey are summarized as follows.

- It seems that graduate theses written on logistics and supply chains are mostly held at the master level and there is not much theses on this area at the doctorate level. It is thought the reason of that is the majority of the universities provide master education than doctorate education.

- The theses in these areas are mostly written in Turkish and the second most commonly used language is English. Very few theses were found in French and German.

- It is reached as the result that the majority of master and doctorate theses in logistics are written in public universities.

- The majority of theses written on logistics often occur in few cities of Turkey. The three most studied provinces are Istanbul, Izmir and Ankara. These 3 cities constitute more than $70 \%$ of the theses written. 
- It seems that a limited number of master theses were prepared until 2000. After that year, significant increases have been observed in the theses. It seems that a limited number of doctorate theses were made until 2007. Significant increases are seen in the doctorate theses with the year 2007 .

- It is seen that most of the master and doctorate theses written in field logistics and supply chain are written in cities Istanbul, Izmir and Ankara. It is noteworthy that in some cities there are no doctorate theses. It is obtained the result that most cities have very few theses made in logistics and supply chain.

- The highest numbers of theses made in logistics were written in Dokuz Eylül University which is 70. All of theses written in logistics are located in three cities Istanbul, Izmir and Ankara. In supply chain field, the highest numbers of theses were written in Istanbul Technical University with 57 theses.

- It was determined the number of theses written in the field of logistics according to institute level. The Institute of Social Sciences is the first place followed by the Institute of Natural and Applied and Institute of Defense Science. In supply chain field, Institute of Natural and Applied Sciences is the first. The second is Institute of Social Sciences. Other institutes consist less than $10 \%$ of all theses in the field of logistics and supply chain. Also it was received that some institutes have only master theses and some have only doctorate theses.

- The logistic word used 324 times is the most used key word in theses of logistics field. This is followed by the logistics management key word used 88 times. This number is followed by supply chain management with 55 and reverse logistics with 54 . Most of the theses in supply chain field were about management. After that performance was one of the most used keywords.

\section{References}

Afatoğlu, A. (2013). Lojistiğin 2013 Atılımı, Turkishtime, Mayıs 1-25.

Ahi, B. \& Kildan, O. (2013). An Overview of Postgraduate Thesis Within The Field of PreSchool Education in Turkey (2002-2011), Mehmet Akif Ersoy Üniversitesi Ë̆itim Fakültesi Dergisi, 1 (27), pp. 23-46.

Bowersox, D.J. (1969). Readings in Physical Distribution Management: The Logistics of Marketing. Eds. Bowersox, D.J., La Londe, B.J., and Smykay, E.W., MacMillan, New York.

Babacan, M. (2003). Lojistik Sektörünün Ülkemizdeki Gelişimi ve Rekabet Vizyonu, Ege Akademik Bakıs , 3 (1), İzmir, Türkiye, 10, 8-15.

Chopra, S. \& Meindl, P. (2016). Supply Chain Management (2th edition). Pearson.

Christopher, M. (1998). Logistic and Supply chain Management. Financial Times Professional Limited, 1998, pp. 17-21.

Ganeshan, R., Jack, E., Magazine, M.J., \& et All (1999). Taxonomic Review of Supply Chain Management Research. In: Ganeshan, R, and Magazine, M., (Eds) Quantitative Models for Supply Chain Management, Kluwer Academic Dodrecht, The Netherlands.

Hammer, M. (2001). The Superefficient Company, Harvard Business Review, Vol. 79, No.9, p.84.

Handfield, R. B. \& Nicholas, E. L. (1999). Introduction to Supply Chain Management, Prentice-Hall, Inc., New Jersey.

Houlihan, J.B. (1985). International Supply Chain Management, Internatioanal Journal of Physical Distribution and Materials Management, Vol.15, No.1, pp. 22-38.

Kehoe, D. \& Boughton, N. (2001). Internet based supply chain management: A classification of approaches to manufacturing planning and control, Internatioal Journal of Operations \& Production Management, Vol 21, No.4, pp. 516-524. 
Martinez, M. A., Cobo, M. J., Herrera, M. \& Herrera-Viedma, E. (2015). Analyzing the scientific evolution of social work using science mapping. Research on Social Work Practice, 25(2), 257-277.

Metz, P.J. (1998), Demystifying Supply Chain Management, Supply Chain Management Review, 1998.

Özdemir, A. İ. (2004). Tedarik Zinciri Yönetiminin Gelişimi, Süreçleri ve Yararları, Erciyes Üniversitesi Iktisadi ve İdari Bilimler Fakültesi Dergisi, Sayı: 23, Temmuz-Aralık 2004, pp. 87-96.

Ross, D.F. (1998). Competing Through Supply Chain Management: Creating MarketWinning Strategies Through Supply Chain Partnerships, Kluwer Academic Publishers, Boston.

T.R. Ministry of Development, (2013). Onuncu Kalkınma Planı 2014-2023, Ankara, 1-199.

Tan, K.C. (2001). A framework of supply chain maangement literature, European Journal of Purchasing\&Supply Management, Vol.7, pp. 39-48.

Tozanll, O., Duman, G. M., Kongar, E. \& Gupta, S. M. (2017). Environmentally Concerned Logistics Operations in Fuzzy Environment: A Literature Survey. Logistics 2017, 1 (1), 4, pp. 1-42.

\section{Appendix}

The algorithm to find most used keywords is given below.

Sub MakeWordList()

Dim InputSheetAs Worksheet

Dim WordListSheetAs Worksheet

Dim PuncCharsAs Variant, $\mathrm{x}$ As Variant

Dim i As Long, $r$ As Long

Dim txt As String

Dim wordCnt As Long

Dim AllWordsAs Range

Dim PC AsPivotCache

Dim PT As PivotTable

Application .ScreenUpdating $=$ False

Set InputSheet $=$ ActiveSheet

Set WordListSheet $=$ Worksheets.Add(after:=Worksheets(Sheets.Count))

WordListSheet.Range("A1") = "All Words"

WordListSheet.Range("A1").Font.Bold = True

InputSheet.Activate

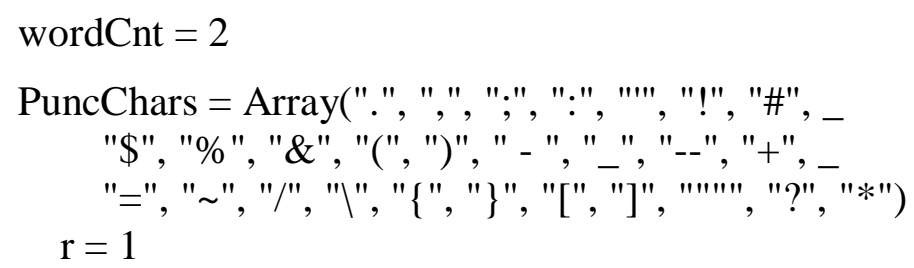

